\title{
Tell it like it is: Experience in mitral valve surgery does matter for improved outcomes in mitral valve infective endocarditis
}

\author{
Syed T. Hussain, MD, ${ }^{a}$ Eugene H. Blackstone, MD, ${ }^{\mathrm{a}, \mathrm{b}}$ and Gösta B. Pettersson, MD, PhD ${ }^{\mathrm{a}}$
}

\author{
From the ${ }^{\mathrm{a}}$ Department of Thoracic and Cardiovascular Surgery, Heart and Vascular Institute and ${ }^{\mathrm{b}}$ Department of \\ Quantitative Health Sciences, Research Institute, Cleveland Clinic, Cleveland, Ohio. \\ Funding was provided by Cleveland Clinic. \\ Disclosures: Authors have nothing to disclose with regard to commercial support. \\ Received for publication Sept 8, 2017; accepted for publication Sept 8, 2017; available ahead of print Oct 5, 2017. \\ Address for reprints: Gösta B. Pettersson, MD, PhD, Department of Thoracic and Cardiovascular Surgery, Cleve- \\ land Clinic, 9500 Euclid Ave/Desk J4-1, Cleveland, OH 44195 (E-mail: petterg@ccf.org). \\ J Thorac Cardiovasc Surg 2017;154:1904-5 \\ $0022-5223 / \$ 36.00$ \\ Copyright $\subset 2017$ by The American Association for Thoracic Surgery \\ https://doi.org/10.1016/j.jtcvs.2017.09.036
}

Supplemental material is available online.

Mitral valve (MV) repair rather than replacement for infective endocarditis (IE) has demonstrated lower operative mortality, better durability, and better long-term survival. $^{1-5}$ Toyoda and colleagues' report $^{6}$ in this issue of the Journal is the latest to highlight the benefits of repair. They compare outcomes of 1970 patients undergoing isolated primary $\mathrm{MV}$ repair $(\mathrm{n}=367,19 \%)$ or replacement ( $\mathrm{n}=1603,81 \%$ ) for active IE in New York and California. MV repair versus replacement was associated with lower mortality and better 12-year survival (68.8\% vs $53.5 \%)$, less recurrent IE (4.7\% vs $9.5 \%$ ), and similar occurrence of reoperation $(9.1 \%$ vs $8.6 \%)$. However, repairs performed by a high-volume MV surgeon ( $\geq 25$ annually for any etiology) were 5 times less likely to require reoperation within 1 year than those performed by a lower-volume surgeon $(2 \%$ vs $9.2 \%)$.

Nationwide, the proportion of repairs for regurgitation caused by degenerative MV disease is $41 \%$ to $61 \%$; lowvolume surgeons are more likely to replace the valve, and patients have worse survival and lower freedom from reoperation. $^{7-10}$ Similar trends have been observed for many other operations, eg, patients undergoing emergency surgery for acute aortic dissection by low-volume surgeons and centers have twice the risk-adjusted mortality of those undergoing surgery by high-volume providers. ${ }^{\text {E1,E2 }}$

According to new The American Association for Thoracic Surgery consensus guidelines for surgical treatment of IE, "Mitral valve repair is the preferred choice whenever possible" (Recommendation 5-7). ${ }^{\text {E3 }}$ In addition to the normal benefits of repair over replacement, superior

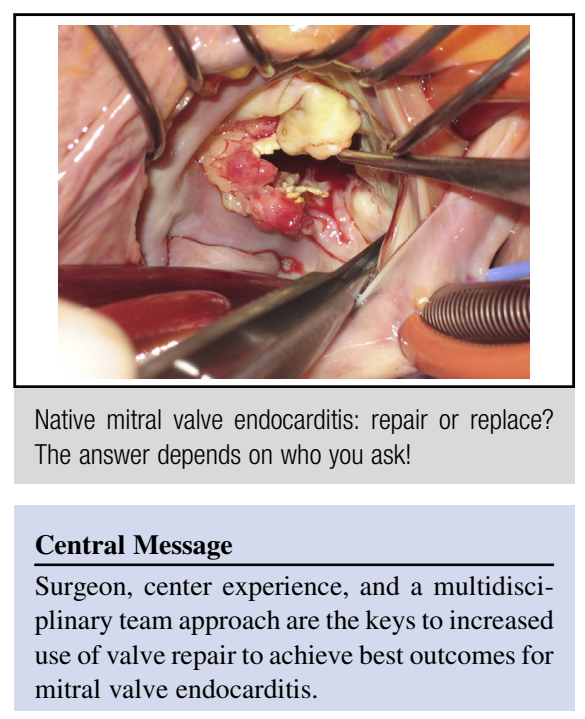

See Article page 1906.

freedom from recurrent mitral IE is the rationale for favoring repair. The message is being heard, because during the period studied by Toyoda and colleagues, ${ }^{6}$ the prevalence of MV repair almost doubled, from $10.7 \%$ to $19.4 \%$.

One major deficit of Toyoda and colleagues' administrative dataset analysis (acknowledged by the authors) was nonavailability of extensiveness of valve pathology, which affects both feasibility of repair and outcomes. ${ }^{6}$ Complexity of $\mathrm{MV}$ repair for invasive IE varies with pathology and is more likely to require patch repairs of missing and excised leaflet tissue in addition to standard repair techniques. Although a few surgeons report repair in a high proportion of infected MVs, de Kerchove and colleagues ${ }^{2}$ showed that repairs including a patch (in $61 \%$ of their patients) fail more often than repairs not requiring a patch. Limitations, success, and durability of extensive patch repairs are unknown. Mitral annular calcification, not uncommon in patients with MV IE, adds further to operative difficulty. The optimum proportion of repairs remains to be discovered and will vary depending on how comfortable surgeons are with repair when leaflet resection is required.

Defining "Center of Excellence," "minimum surgical volume," and "referent surgeon" remains challenging. ${ }^{\text {E4 }}$ Referring patients with IE to high-volume centers, along with other collaborative quality-improvement initiatives, 
should be encouraged to improve outcomes, similar to recommendations for other high-risk surgical procedures associated with strong volume-outcome relationships. ${ }^{\text {E. }}$ Surgery for IE carries the greatest risk of any valve surgery, and the team caring for these patients should include an experienced surgeon who has mastered the full armamentarium of MV repair techniques.

\section{References}

1. Muehrcke DD, Cosgrove DM III, Lytle BW, Taylor PC, Burgar AM, Durnwald CP, et al. Is there an advantage to repairing infected mitral valves? Ann Thorac Surg. 1997;63:1718-24.

2. de Kerchove L, Price J, Tamer S, Glineur D, Momeni M, Noirhomme P, et al. Extending the scope of mitral valve repair in active endocarditis. J Thorac Cardiovasc Surg. 2012;143(4 suppl):S91-5.

3. Shimokawa T, Kasegawa H, Matsuyama S, Seki H, Manabe S, Fukui T, et al. Long-term outcome of mitral valve repair for infective endocarditis. Ann Thorac Surg. 2009;88:733-9.
4. Feringa HH, Shaw LJ, Poldermans D, Hoeks S, van der Wall EE, Dion RA, et al. Mitral valve repair and replacement in endocarditis: a systematic review of literature. Ann Thorac Surg. 2007;83:564-70.

5. Shang E, Forrest GN, Chizmar T, Chim J, Brown JM, Zhan M, et al. Mitral valve infective endocarditis: benefit of early operation and aggressive use of repair. Ann Thorac Surg. 2009;87:1728-34.

6. Toyoda N, Itagaki S, Egorova NN, Tannous H, Anyanwu AC, El-Eshmawi A, et al, Real-world outcomes for native mitral valve endocarditis. J Thorac Cardiovasc Surg. 2017;154:1906-12.e9.

7. Chikwe J, Toyoda N, Anyanwu AC, Itagaki S, Egorova NN, Boateng P, et al. Relation of mitral valve surgery volume to repair rate, durability, and survival J Am Coll Cardiol. April 24, 2017 [Epub ahead of print].

8. LaPar DJ, Ailawadi G, Isbell JM, Crosby IK, Kern JA, Rich JB, et al. Virginia Cardiac Surgery Quality Initiative. Mitral valve repair rates correlate with surgeon and institutional experience. J Thorac Cardiovasc Surg. 2014;148:995-1004.

9. Bolling SF, Li S, O'Brien SM, Brennan JM, Prager RL, Gammie JS. Predictors of mitral valve repair: clinical and surgeon factors. Ann Thorac Surg. 2010;90: 1904-12.

10. Gammie JS, O’Brien SM, Griffith BP, Ferguson TB, Peterson ED. Influence of hospital procedural volume on care process and mortality for patients undergoing elective surgery for mitral regurgitation. Circulation. 2007;115:881-7. 
APPENDIX E1. AATS CONSENSUS GUIDELINES: SURGICAL TREATMENT OF INFECTIVE ENDOCARDITIS (IE) ${ }^{\mathrm{E} 3}$

Who Should Care for and Operate on Patients With IE? Native Aortic Valve IE (Recommendation 1-1)

Patients with suspected IE should ideally be cared for at centers with access to a complete team, including cardiology, infectious disease, cardiac surgery, and other services needed to handle IE complications.

Surgeons operating on patients with IE should be welltrained, experienced valve surgeons who are well versed in the different reconstruction techniques needed by patients with advanced disease.

\section{Native Mitral Valve IE (Recommendation 5-7)}

Mitral valve repair is the preferred choice whenever possible. Adding a prosthetic annuloplasty ring adds minimally, if at all, to the risk of recurrent infection.

When valve replacement is required, it is reasonable to implant a new mechanical or tissue valve, with the choice based on normal criteria.
If there is destruction and invasion, the annulus is reconstructed and the valve prosthesis anchored to the ventricular muscle in an attempt to prevent leakage underneath the prosthesis.

\section{E-References}

E1. Chikwe J, Cavallaro P, Itagaki S, Seigerman M, Diluozzo G, Adams DH. National outcomes in acute aortic dissection: influence of surgeon and institutional volume on operative mortality. Ann Thorac Surg. 2013;95: 1563-9.

E2. Knipp BS, Deeb GM, Prager RL, Williams CY, Upchurch GR Jr, Patel HJ. A contemporary analysis of outcomes for operative repair of type A aortic dissection in the United States. Surgery. 2007;142:524-8.

E3. Pettersson GB, Coselli JS, Hussain ST, Griffin B, Blackstone EH, Gordon SM, et al. AATS Surgical Treatment of Infective Endocarditis Consensus Guidelines Writing Committee. 2016 The American Association for Thoracic Surgery (AATS) consensus guidelines: surgical treatment of infective endocarditis: executive summary. J Thorac Cardiovasc Surg. 2017; 153:1241-58.e29.

E4. McCarthy PM. When is your surgeon good enough? When do you need a "referent surgeon"? Curr Cardiol Rep. 2009;11:107-13.

E5. Finks JF, Osborne NH, Birkmeyer JD. Trends in hospital volume and operative mortality for high-risk surgery. N Engl J Med. 2011;364:2128-37. 